Available online on 15.01.2020 at http://jddtonline.info
Open Access to Pharmaceutical and Medical Research
unrestricted non-commercial use, provided the original work is properly cited

Open 2 Access

Research Article

\title{
Documentation of Indigenous Knowledge on Folk Medicine in Doddakavalande Doddakavalande Hobli, Nanjangud Taluk of Mysore District, Karnataka
}

\author{
Nagalakshmi M, Rashmi S* \\ Post Graduate Department of Botany, JSS College of Arts, Commerce and Science (Autonomous), Ooty road, Mysuru, Karnataka, India
}

\begin{abstract}
An ethnobotanical survey was conducted to collect information from traditional healers on the use of herbal medicine in Doddakavalande Hobli, Nanjangud taluk of Mysore District. The indigenous knowledge of local healers was documented through questionnaire and personal interviews. In the present study, about 19 respondents of age group between 50 to 89 yrs gave information of traditional medicin es used to cure different ailments. Of about 35 plant species belonging to 26 families were used for the treatment of human ailments. In which family Fabaceae and Polygonaceae contained 3 plant species, followed by Acanthaceae, Amaranthaceae, Apocynaceae, Cucurbitaceae, Poaceae contained 2 species each, and the rest of the families Amaryllidaceae, Anacardiaceae, Apiaceae, Aristolochiaceae, Asteraceae, Cleastraceae, Crassulaceae, Lamiaceae, Lecythidaceae, Meliaceae, Olaceae, Phylanthaceae, Piperaceae, Plumbaginaceae, Poaceae, Polygonaceae, Rutaceae, Smilacaceae, Solanaceae, Styracaceae and Zingiberaceae. Habit wise analysis of medicinal plant species used indicated that herbs (19 species) were the most preferred life form followed by trees ( 8 species), shrubs ( 5 species) and climbers ( 3 species) for drug formulation. Herbal formulations were administrated either internally or applied externally depending on the type of ailment. Local people in the study area possess traditional knowledge of medicinal plants to treat various human ailments, therefore it is necessary to preserve the indigenous knowledge on traditional medicines by proper documentation, identification of plant species used, and herbal preparation.
\end{abstract}

Keywords: Ethnobotany, Traditional knowledge, Medicinal plants, Mysore district.

Article Info: Received 19 Nov 2019; $\quad$ Review Completed 10 Dec 2019; $\quad$ Accepted 23 Dec 2019; Available online 15 Jan 2020

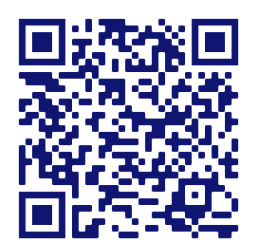

Cite this article as:

Nagalakshmi M, Rashmi S, Documentation of Indigenous Knowledge on Folk Medicine in Doddakavalande Hobli,

Nanjangud Taluk of Mysore District, Karnataka, Journal of Drug Delivery and Therapeutics. 2020; 10(1):39-47

http://dx.doi.org/10.22270/jddt.v10i1.3726

*Address for Correspondence:

Rashmi S, Post Graduate Department of Botany, JSS College of Arts, Commerce and Science (Autonomous), Ooty road, Mysuru, Karnataka, India

\section{INTRODUCTION:}

The close relationship between plants and primitive people of the world gave birth to a new interdisciplinary science called 'Folk medicine' 1. Folk medicine originated from primitive man's reactions or attitudes to natural events. Disease and health were explained by external factors penetrating and harming the body. People's efforts to find solutions to these diseases set up the basis of folk medicine. Consequently, in traditional societies opinions on disease and health were born as a part of folk culture 2. Folk medicine lives among the people as a part of their culture. In traditional societies, any information about a disease is shared by others. This information is passed through the generations ${ }^{3}$.

Traditional healers are often part of a local community, culture and tradition, and continue to have high social standing in many places, exerting influence on local health practice ${ }^{4}$. The world health organisation (WHO) currently recommend and encourage traditional herbal remedies in natural health care programs since these drugs are easily available at low cost and are comparatively safe 5. Folk medicinal surveys are important steps in the identification, selection and development of therapeutic agents from medicinal plants which serves as a base for new compounds with active principles for phytochemical, pharmacological and clinical research ${ }^{6}$.

The documentation of traditional and indigenous knowledge on medicinal plants is important for value addition and upliftment and poverty alleviation of local communities and indigenous people 7. Despite the advances achieved by modern pharmacology and medicine, $80 \%$ of the worldwide population benefits from the contributions of traditional medicine in terms of health care, especially in developing countries, in the absence of a modern medical system ${ }^{8}$.

Mysore district is an impressive place for the natural resources, with its lustre, thick green forest and plant life, 
due to moist deciduous and dry deciduous which provided an opportunity to researcher to enlist medicinal plants with their therapeutic values ${ }^{9}$. Mysore district is having a rich flora of medicinal plants, a very limited area has been documented with a smaller number of medicinal plants used by traditional healers. Hence the present study has been carried out to enlist medicinal plants mentioned in the classical text of ayurvedic formulations and preparations and also by traditional folk healers. It directly helps to know the availability of plant raw material in the growth of pharmaceutical industry to prepare herbal medicines for the benefit of mankind.

\section{MATERIALS AND METHODS}

\subsection{Study Area}

Field survey was targeted custodians of traditional medicine used in treatment of diseases. The survey was conducted during the months of January and February (2019) in 19 selected villages in Doddakavalande hobli of Nanjangud taluk to identify folk practitioners and to collect folk knowledge.

\subsection{Data collection}

With a prior informed consent, authentic and well-known herbal practitioners were identified. The data was collected through interviews and discussion with traditional participants in the study area using the questionnaires. During the survey, information on age, sex, level of education, ethnicity and occupation of informants was reported. Personal interviews with local language documented human health indications treated, local names of plants used, growth form, degree of management (wild/cultivated), abundance, parts used, condition of part used (fries/dried), methods of preparation, dosage prescription, diet restrictions and administrations ${ }^{2}$.

\subsection{Data analysis}

Quantitative techniques were employed to compare uses and the cultural importance of different plant species. The techniques employed for data analysis was Informant consensus factor (ICF). ICF was used to evaluate the healer's consensus on managing various ailments. This method was employed to analyse the agreement of the informant's knowledge on each category of ailment. The high ICF value indicate that only a few plant species are used by a large number of traditional petitioners, while low ICF value indicates low consensus on the usage of medicinal plants among respondents in the utilization of medicinal plants for the treatment of within a group of ailments ${ }^{10}$.

Informant consensus factor was calculated by the formula: ICF = Nur-Nt/ Nt-1

Where, Nur is the total number of use reports cited for any given specimens. Nt is the number of species reported in each category.

\section{RESULTS AND DISCUSSION}

In the present study, about 19 respondents of age group between 50 to 89 yrs gave information of traditional medicines used to cure various diseases in Doddakavale hobli. Most of the healers were from the age group of 65-69 yrs (Fig 1). The gender ratio were $63.15 \%$ male and $36.84 \%$ female individuals. All over the globe, male rather than female healers were involved in herbal medicine ${ }^{11}$. In Western Ghats, a high proportion of key informants being male of 50 years and above. Age old people have more knowledge on medicinal plants ${ }^{12}$. As far as the occupation of respondents is concerned, only $5 \%$ of them practiced traditional medicine as their only source of income. Most of them were primarily agriculturists who also practiced herbal medicine as the secondary occupation. Majority of the traditional healers acquired the healing knowledge from their ancestors. A considerable number of healers had an experience of 30 to 65 years in traditional medicinal practices.

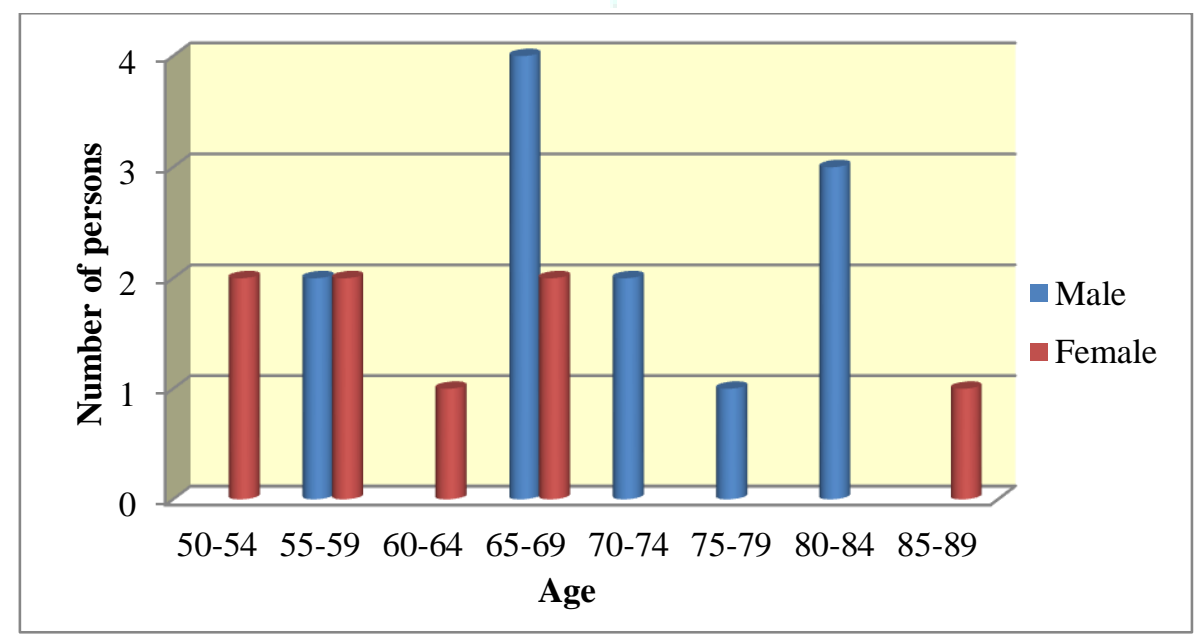

Figure 1: Number of traditional healers by Age and Gender 
Table 1: Enumeration of plants used for the treatment of some common diseases in Doddakavalande hobli- Nanjangud taluk, Mysore district

\begin{tabular}{|c|c|c|c|c|c|c|}
\hline $\begin{array}{l}\text { Sl. } \\
\text { No }\end{array}$ & Botanical Name & Local Name & Common Name & Family & Habit & Parts Used \\
\hline 1 & Albizia amara Roxb. & Chujjulu chakke & Bitter Albizia & Fabaceae & Tree & Bark \\
\hline 2 & Alternanthera sessilis L. & Honagone soppu & Sessile joyweed & Amaranthaceae & Herb & Whole plant \\
\hline 3 & Allium sativum L. & Bellulli & Garlic & Amaryllidaceae & Herb & Bulb \\
\hline 4 & Amorpha fruticosa $\mathrm{L}$. & Kemberagu soppu & False indigo & Fabaceae & Shrub & Leaves \\
\hline 5 & Andrographis echioides L. & Godhi barsana & $\begin{array}{l}\text { False } \\
\text { waterwillow }\end{array}$ & Acanthaceae & Herb & Leaves \\
\hline 6 & $\begin{array}{l}\text { Andrographis paniculata } \\
\text { Burm.f. }\end{array}$ & $\begin{array}{l}\text { Nelavembu } \\
\text { (Kalamegha) }\end{array}$ & Green chirayta & Acanthaceae & Herb & $\begin{array}{l}\text { Leaves, } \\
\text { Roots }\end{array}$ \\
\hline 7 & Asarum canadense L. & Kallu shunti & Wild ginger & Aristolochiaceae & Herb & Rhizome \\
\hline 8 & Azadirachta indica A. juss & Bevu & Neem & Meliaceae & Tree & Bark \\
\hline 9 & Bambusa vulgaris Schrad. & Kalale & Tender bamboo & Poaceae & Tree & Stem \\
\hline 10 & $\begin{array}{l}\text { Bryophyllum pinnatum (Lam) } \\
\text { Oken }\end{array}$ & Pathrachatta & Cathedral bells & Crassulaceae & Herb & Leaves \\
\hline 11 & Calotropis gigantea $\mathrm{L}$. & Yakkada gida & Calotropis plant & Apocynaceae & Shrub & Latex \\
\hline 12 & $\begin{array}{l}\text { Celastrus paniculatus } \\
\text { Willd. }\end{array}$ & Kariganne (Kougilu) & Black oil plant & Cleastraceae & Tree & Leaves \\
\hline 13 & Celosia argentea $\mathrm{L}$. & Anne soppu & $\begin{array}{l}\text { Silver } \\
\text { cockscomb }\end{array}$ & Amaranthaceae & Herb & Flowers \\
\hline 14 & Clerodendrum inerme $\mathrm{L}$. & Vishapradi (vishapuri) & Khejri tree & Fabaceae & Tree & Leaves \\
\hline 15 & Citrus limon L. & Nimbe & Lemon & Rutaceae & Shrub & Pulp \\
\hline 16 & Cuminum cyminum L. & Jeerige & Cumin & Apiaceae & Herb & Seed \\
\hline 17 & Curcuma longa L. & Arishina & Turmeric & Zingiberaceae & Herb & Rhizome \\
\hline 18 & $\begin{array}{l}\text { Corallocarpus epigaeus Rottl. } \\
\text { ex. wild. }\end{array}$ & Akashamallige & $\begin{array}{l}\text { Red fruit } \\
\text { creeper }\end{array}$ & Cucurbitaceae & Tree & Roots \\
\hline 19 & Couroupita guianensis Aubl. & Nagamalli & $\begin{array}{l}\text { Mysterious } \\
\text { naga }\end{array}$ & Lecythidaceae & Tree & Roots \\
\hline 20 & Diplocyclos palmatus C. Jeffrey & Linga konde balli & $\begin{array}{l}\text { Striped } \\
\text { cucumber }\end{array}$ & Cucurbitaceae & Climber & $\begin{array}{l}\text { Leaves and } \\
\text { fruits }\end{array}$ \\
\hline 21 & Eleusine coracana $\mathrm{L}$. & Ragi kaddi & Finger millet & Poaceae & Herb & Stem \\
\hline 22 & Hemidesmus indicus L. & $\begin{array}{l}\text { Nannari plant (Halu } \\
\text { balli) }\end{array}$ & $\begin{array}{l}\text { Indian } \\
\text { sarasaparilla }\end{array}$ & Apocynaceae & Herb & Roots \\
\hline 23 & Ocimum tenuiflorum L. & Tulasi & Holy basil & Lamiaceae & Herb & Leaves \\
\hline 24 & $\begin{array}{l}\text { Persicara glabra (Willd) M. } \\
\text { Gomez }\end{array}$ & Niru kanigalu & Denseflower & Polygonaceae & Shrub & $\begin{array}{l}\text { Leaves and } \\
\text { flowers }\end{array}$ \\
\hline 25 & Persicaria bistorta L. & Anjbar & Meadow Bistort & Polygonaceae & Herb & Stem \\
\hline 26 & $\begin{array}{l}\text { Plumbago auriculata } \\
\text { Lam. }\end{array}$ & Chithramulika & Plumbago & Plumbaginaceae & Shrub & Roots \\
\hline 27 & Piper nigrum L. & Menasu & Pepper & Piperaceae & Herb & Seeds \\
\hline 28 & Pistacia lenticus L. & Rala (Gondu) & Mastic tree & Anacardiaceae & Shrub & Gum \\
\hline 29 & Phyllanthus niruri L. & Keela nelli & Stone breaker & Phyllanthaceae & Herb & Leaves \\
\hline 30 & Rheum emodi L. & Revand chini & $\begin{array}{l}\text { Himalayan } \\
\text { rhubarb }\end{array}$ & Polygonaceae & Herb & Roots \\
\hline 31 & Smilax chinensis L. & Madhusnuhi & China root & Smilacaceae & Herb & Whole plant \\
\hline 32 & Solanum nigrum L & Ganike soppu & $\begin{array}{l}\text { Black night } \\
\text { shade }\end{array}$ & Solanaceae & Herb & Leaves \\
\hline 33 & Styrax benzoin Dryand & Chilaka dupa & Benzoin plant & Styracaceae & Tree & $\begin{array}{l}\text { Flowers and } \\
\text { leaves }\end{array}$ \\
\hline 34 & Syringa vulgaris L. & Ambu & Lilac & Olaceae & Climber & Leaves \\
\hline 35 & $\begin{array}{l}\text { Tanacetum cinerariifolium Sch. } \\
\text { Bip. }\end{array}$ & Kallu suseege & $\begin{array}{l}\text { Pyrethrum } \\
\text { plant }\end{array}$ & Asteraceae & Herb & Roots \\
\hline
\end{tabular}


Of about 35 traditional plant species belonging to 26 families were used for the treatment of human ailments. Scientific names, common names, local names and parts used has been recorded (Table 1). The medicinal plants recorded in the target area belong to 26 families, in which family Fabaceae and Polygonaceae contained 3 plant species, followed by Acanthaceae, Amaranthaceae, Apocynaceae, Cucurbitaceae, Poaceae contained 2 species each, and the rest of the families Amaryllidaceae, Anacardiaceae, Apiaceae, Aristolochiaceae, Asteraceae, Cleastraceae, Crassulaceae, Lamiaceae, Lecythidaceae, Meliaceae, Olaceae, Phylanthaceae, Piperaceae, Plumbaginaceae, Poaceae, Polygonaceae, Rutaceae, Smilacaceae, Solanaceae, Styracaceae,
Zingiberaceae contained one plant species each (Fig 2). Traditional healers of Zimbabwe used plant species of Fabaceae plants for wounds, urinary and microbial infections ${ }^{13}$. In Laguna, Lamiaceae is the third important plant family used in the study area for treating cough, cold, sore nose, wound and skin diseases and also reported that Lamiaceae plants are mainly used for stomach related problems and also as relaxant ${ }^{14}$. In Laklei village of Mexico, the local community used high percentage of plant species of Apocynaceae followed by Euphorbiaceae and Fabaceae utilization of large number of life forms of different families indicated the prevalence of highly diverse plant species in the study area ${ }^{15}$.

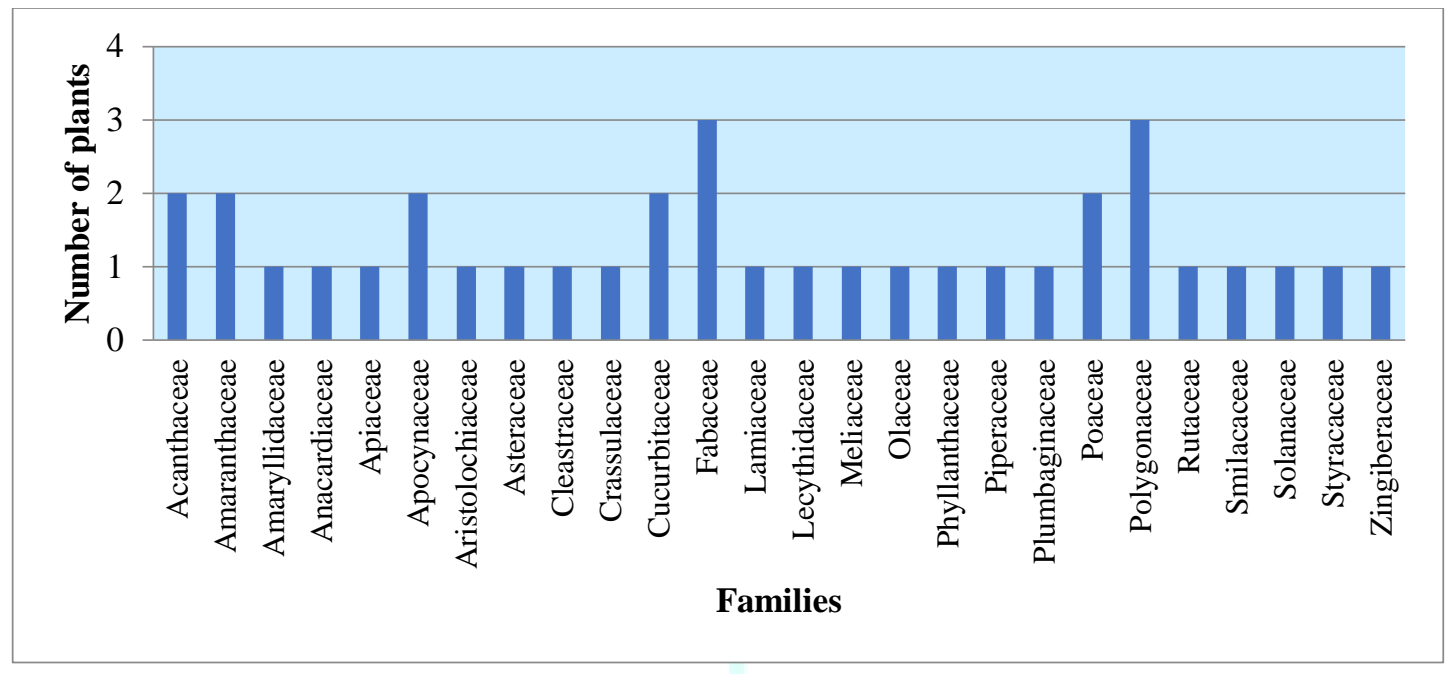

Figure 2: Number of plant species family wise used in the treatment of various diseases

Habit wise analysis of medicinal plant species used indicated that herbs (19 species) were the most preferred life form followed by trees ( 8 species), shrubs (5 species) and climbers (3 species) for drug formulation (Fig 3). The traditional healers preferred wild plants over the cultivated ones for herbal drug formulation. In which, 20 species were collected from wild and 15 species were collected from cultivated plants. Among the wild plants, herb (51\%) were the most preferred life form for herbal formulation, followed by trees (21\%), shrubs (16\%) and climbers (5\%). In western
Himalaya people used more native species than the exotic species ${ }^{16}$. The resident folk practitioners of Ethiopia used tree species mainly for the herbal formulation as they are available all through the seasons ${ }^{17}$. Among all the plant parts are used for treatments, leaf is most commonly used in the preparation of different remedies in the study area. In Andhra Pradesh, leaf part are commonly used for the formulation, leaves have higher healing potential than the other parts of the plant. According to the folk people, leaves are easily accessible and most abundant in the area 18 .

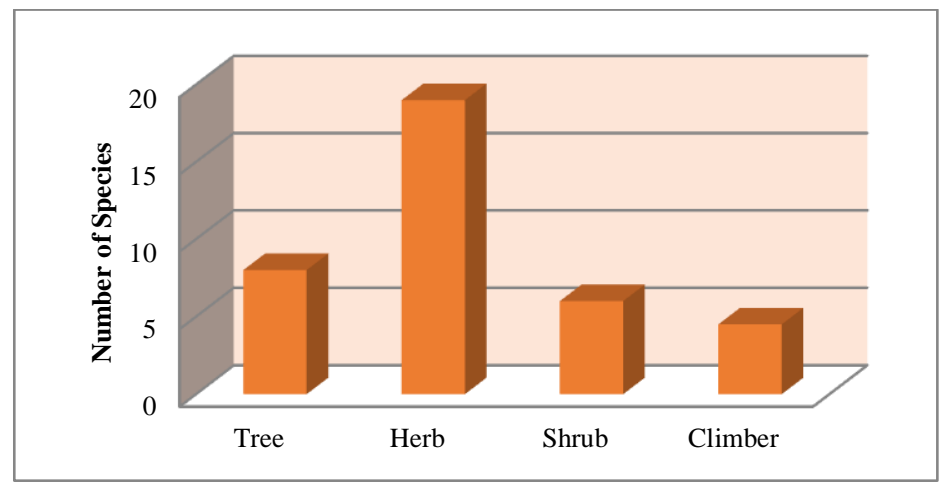

Figure 3: Life form of plants used as medicinal plants

The most commonly used plant parts to prepare herbal remedies were leaves (37\%), followed by roots $(17 \%)$, stem $(8 \%)$, rhizome $(6 \%)$, whole plant $(6 \%)$, flowers $(6 \%)$, bark (5\%), seeds (3\%), fruits (3\%), gum (3\%), pulp (3\%) and bulb $(3 \%)$. The use of plant materials also depended on ISSN: 2250-1177 their availability, since roots and bark are available in plenty through seasons, most of the healers preferred these parts of formulation. The less preferred parts of the plants were flowers, seeds and fruits (Fig 4). The leaves of the ethnomedicinal plants were also documented to be used by 
the majority of remedies in traditional medicines in several reports followed by roots 19,20 .

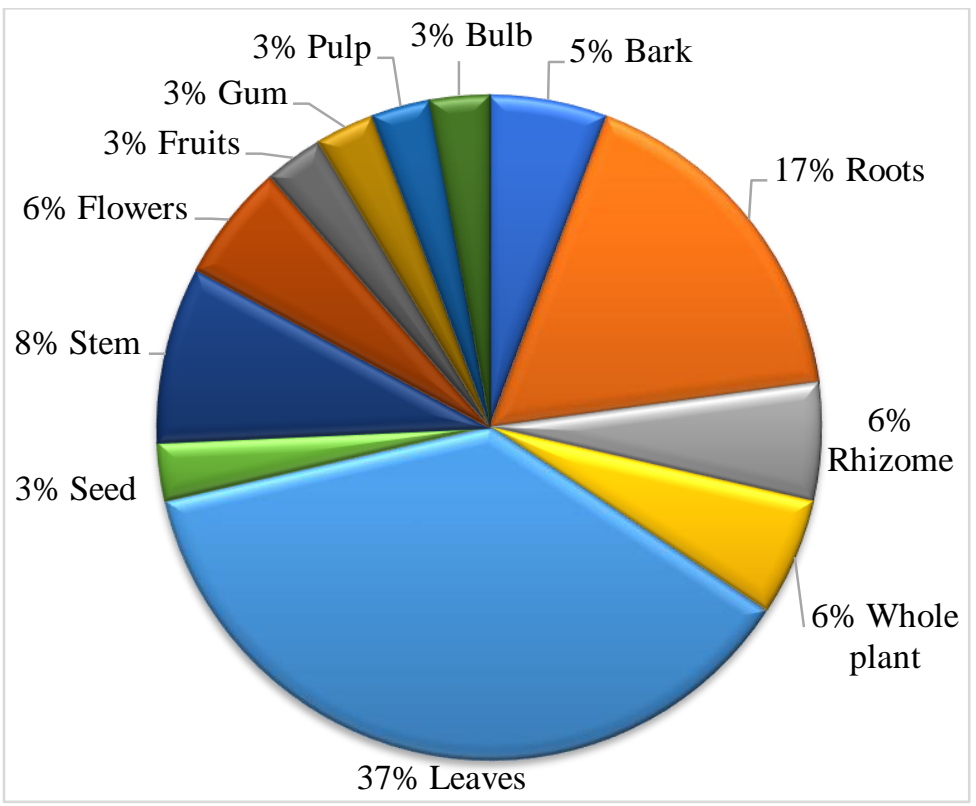

Figure 4: Plant parts used for the management of various healthcare problems

Table 2: Enumeration of recipes, method of preparation, mode of administration used in the treatment of some diseases among the residents of Doddakavalande hobli- Nanjangud taluk, Mysore district

\begin{tabular}{|c|c|c|c|c|c|c|}
\hline Ailment & Recipe & $\begin{array}{l}\text { Traditional } \\
\text { Solvent of } \\
\text { Choice }\end{array}$ & $\begin{array}{l}\text { Method of } \\
\text { Preparation }\end{array}$ & $\begin{array}{l}\text { Mode of } \\
\text { Administration }\end{array}$ & $\begin{array}{l}\text { Duration and } \\
\text { Dosage }\end{array}$ & $\begin{array}{l}\text { Diet } \\
\text { restrictions }\end{array}$ \\
\hline Burning & $\begin{array}{l}\text { Grind Plumbago Roots } \\
\text { and turmeric rhizome }\end{array}$ & Water & Paste & Topical & 1 day & $\begin{array}{l}\text { No diet } \\
\text { Restrictions }\end{array}$ \\
\hline Calculi & $\begin{array}{l}\text { Cathedral bell leaves } \\
\text { are mixed with fish } \\
\text { stones, grinded }\end{array}$ & Honey & Decoction & Oral & $\begin{array}{l}\text { Intake } 10 \text { grams } \\
\text { twice per day till } \\
\text { recover }\end{array}$ & $\begin{array}{l}\text { Do not } \\
\text { eat/drink } \\
\text { tomato } \\
\text { seeds, fresh } \\
\text { milk and } \\
\text { soft drinks }\end{array}$ \\
\hline $\begin{array}{l}\text { Centipede } \\
\text { bite }\end{array}$ & Finger millet stem & Chewing & No & Oral & 1 day & $\begin{array}{l}\text { NO diet } \\
\text { restrictions }\end{array}$ \\
\hline Diabetes & $\begin{array}{l}\text { Khejri tree leaves are } \\
\text { grinded and filtered }\end{array}$ & Water & Decoction & Oral & $\begin{array}{l}\text { Take } 50 \mathrm{ml} \text { twice } \\
\text { per day up to } 9 \\
\text { days }\end{array}$ & $\begin{array}{l}\text { Do not eat } \\
\text { oily food, } \\
\text { vegetables } \\
\text { and grains }\end{array}$ \\
\hline Dog bite & $\begin{array}{l}\text { Densflower plant } \\
\text { leaves mixed with } \\
\text { garlic cloves and } \\
\text { pepper seeds, grinded }\end{array}$ & Water & Paste & Topical & $\begin{array}{l}\text { By using coconut } \\
\text { oil wash the dog } \\
\text { bited area then } \\
\text { apply the paste. } \\
\text { Next day clean } \\
\text { wound area with } \\
\text { chick pea flour } \\
\text { then again apply } \\
\text { the paste for } 1 \\
\text { week }\end{array}$ & $\begin{array}{l}\text { Do not eat } \\
\text { brinjal } \\
\text { and } \\
\text { pumpkin }\end{array}$ \\
\hline $\begin{array}{l}\text { Hemangioma } \\
\text { (Skin } \\
\text { disease) }\end{array}$ & $\begin{array}{l}\text { Fresh leaves of black } \\
\text { oil plant mix with } \\
\text { Calotropis latex, lemon } \\
\text { juice, garlic cloves and } \\
\text { then grind well to } \\
\text { make a paste }\end{array}$ & $\begin{array}{l}\text { Calatropis } \\
\text { latex and } \\
\text { lemon juice }\end{array}$ & Paste & Topical & $\begin{array}{l}\text { Directly apply up } \\
\text { to } 1 \text { month }\end{array}$ & $\begin{array}{l}\text { No diet } \\
\text { restrictions }\end{array}$ \\
\hline $\begin{array}{l}\text { Hemiplegia } \\
\text { (Stroke) }\end{array}$ & $\begin{array}{l}\text { Benzoin flowers and } \\
\text { leaves, Pyrethrum } \\
\text { roots are dried and } \\
\text { grinded to make a } \\
\text { powder then add } \\
\text { kasturi musk (it is } \\
\text { extract from deer), }\end{array}$ & $\begin{array}{l}\text { Olive oil } \\
\text { and honey }\end{array}$ & Syrup & Oral & $\begin{array}{l}\text { Take } 10 \mathrm{ml} \text { per a } \\
\text { day up to } 4 \text { weeks }\end{array}$ & $\begin{array}{l}\text { Do not eat } \\
\text { cold and } \\
\text { sour items }\end{array}$ \\
\hline Hepatitis A & Stone breaker leaves & Cow milk & Decoction & Oral and Topical & Decoction to be & Only eat \\
\hline
\end{tabular}




\begin{tabular}{|c|c|c|c|c|c|c|}
\hline $\begin{array}{l}\text { (White } \\
\text { jaundice) }\end{array}$ & $\begin{array}{l}\text { are mixed with cow } \\
\text { milk and grind well, } \\
\text { make a paste and as } \\
\text { well as decoction }\end{array}$ & & & & $\begin{array}{l}\text { intake- } 50 \mathrm{ml} \text { once } \\
\text { per day and paste } \\
\text { will be apply to the } \\
\text { head and bath upto } \\
5 \text { days }\end{array}$ & $\begin{array}{l}\text { curd rice } \\
\text { and butter } \\
\text { milk }\end{array}$ \\
\hline Hepatitis B & $\begin{array}{l}\text { Wild ginger rhizome } \\
\text { and china root (whole } \\
\text { plant) are grinded to } \\
\text { make a paste and add } \\
\text { some honey to make a } \\
\text { tonic }\end{array}$ & Honey & Tonic & Oral & $\begin{array}{l}\text { Intake } 20 \mathrm{ml} \text { once } \\
\text { per day up to } 3 \\
\text { weeks }\end{array}$ & $\begin{array}{l}\text { Do not eat } \\
\text { non- } \\
\text { vegetarian } \\
\text { food }\end{array}$ \\
\hline $\begin{array}{l}\text { Hepatitis C } \\
\text { (Yellow } \\
\text { jaundice) }\end{array}$ & $\begin{array}{l}\text { Sessile joy weed plant } \\
\text { is prepared as food } \\
\text { without oil }\end{array}$ & $\begin{array}{l}\text { Boiled } \\
\text { water }\end{array}$ & Food & Oral & 6 months & $\begin{array}{l}\text { Do not eat } \\
\text { oily food } \\
\text { and grains }\end{array}$ \\
\hline Leucorrhoea & $\begin{array}{l}\text { Tender bamboo will } \\
\text { be cut into pieces } \\
\text { (Tender bamboo is too } \\
\text { poisonous, so they } \\
\text { have to be washed up } \\
\text { to } 10 \text { times.), add } \\
\text { anjbar stem and } C \text {. } \\
\text { argentea flowers mix } \\
\text { well and grind, filter } \\
\text { the extract }\end{array}$ & Honey & Tonic & Oral & $\begin{array}{l}\text { Intake tonic twice } \\
\text { per a day up to } 3 \\
\text { weeks }\end{array}$ & $\begin{array}{l}\text { Do not use } \\
\text { any kind of } \\
\text { oil foods and } \\
\text { do not eat } \\
\text { chilli. }\end{array}$ \\
\hline Malaria fever & $\begin{array}{l}\text { Mix Neem bark, Albizia } \\
\text { bark, turmeric } \\
\text { rhizome, cumin seeds } \\
\text { and grind well }\end{array}$ & $\begin{array}{l}\text { Boiled } \\
\text { water }\end{array}$ & Tonic & Oral & $\begin{array}{l}10 \mathrm{ml} \text { for children, } \\
50 \mathrm{ml} \text { for adults } \\
\text { and old persons } \\
\text { once per day for } 1 \\
\text { week }\end{array}$ & $\begin{array}{l}\text { No diet } \\
\text { restrictions }\end{array}$ \\
\hline $\begin{array}{l}\text { One side } \\
\text { headache }\end{array}$ & $\begin{array}{l}\text { Holy basil leaf extract } \\
\text { mixed with lemon } \\
\text { juice and small } \\
\text { amount of salt }\end{array}$ & $\begin{array}{l}\text { Lemon and } \\
\text { salt }\end{array}$ & Decoction & Nasal & 2-3 drops for 1 day & $\begin{array}{l}\text { No diet } \\
\text { restrictions }\end{array}$ \\
\hline Piles & $\begin{array}{l}\text { Mastic gum and } \\
\text { revand chini roots are } \\
\text { grinded and filtered }\end{array}$ & Honey & Syrup & Oral & $\begin{array}{l}\text { Intake syrup twice } \\
\text { per a day till } \\
\text { recover }\end{array}$ & $\begin{array}{l}\text { Do not eat } \\
\text { spicy food, } \\
\text { do not eat } \\
\text { forest birds }\end{array}$ \\
\hline $\begin{array}{l}\text { Red lumps } \\
\text { and bumps } \\
\text { on skin }\end{array}$ & $\begin{array}{l}\text { Fresh leaves of false } \\
\text { indigo, lilac and black } \\
\text { night shade are dried } \\
\text { up to } 3-4 \text { days under } \\
\text { sunlight, then grind } \\
\text { well and make a } \\
\text { powder }\end{array}$ & Water & Paste & Topical & $\begin{array}{l}\text { Directly apply the } \\
\text { paste up to } 4 \text { days }\end{array}$ & $\begin{array}{l}\text { Do not eat } \\
\text { salt and } \\
\text { spicy foods, } \\
\text { do not drink } \\
\text { hot drinks } \\
\text { and do not } \\
\text { bath up to } 4 \\
\text { days }\end{array}$ \\
\hline $\begin{array}{l}\text { Ringworm } \\
\text { tinea (Skin } \\
\text { disease) }\end{array}$ & $\begin{array}{l}\text { Striped cucumber } \\
\text { leaves are grinded } \\
\text { well }\end{array}$ & Water & Paste & Topical & 1 month & $\begin{array}{l}\text { No diet } \\
\text { restrictions }\end{array}$ \\
\hline Scorpion bite & $\begin{array}{l}\text { Directly chewing } \\
\text { finger millet stem }\end{array}$ & No & Chewing & Oral & 1 day & $\begin{array}{l}\text { No diet } \\
\text { restrictions }\end{array}$ \\
\hline Snake bite & $\begin{array}{l}\text { Mysterious naga, Red } \\
\text { fruit creeper and } \\
\text { Green chirayta Roots } \\
\text { and leaves are grinded }\end{array}$ & Coconut oil & Decoction & Oral & $3 \mathrm{ml}$ for 3 days & $\begin{array}{l}\text { Do not drink } \\
\text { water before } \\
\text { taking } \\
\text { medicine } \\
\text { and then do } \\
\text { not sleep } \\
\text { one night } \\
\text { after taking } \\
\text { medicine }\end{array}$ \\
\hline Psoriasis & $\begin{array}{l}\text { Indian Sarasaparilla } \\
\text { roots are boiled with } \\
\text { water }\end{array}$ & $\begin{array}{l}\text { Boiled } \\
\text { water }\end{array}$ & Tonic & Oral & $\begin{array}{l}\text { Intake tonic twice } \\
\text { per a day till } \\
\text { recover }\end{array}$ & $\begin{array}{l}\text { Do not eat } \\
\text { oily foods } \\
\text { and chilli }\end{array}$ \\
\hline
\end{tabular}


The inventoried medicinal plants are used by the population of study area in their routine practices to treat range of common ailments and disorders. Nineteen different ailments have been documented, among these the diseases include pathological, gastrointestinal, lever, metabolic and animal bites (Table 2). Almost every plant part is used for the treatment of ailments, either singly or in combination with other plants. To cure Malaria fever, Haemangioma, and Dog bite four types of plant parts will be combined, followed by Snake bite, Leucorrhoea, Red lumps and bumps on skin (three types of plants), Burning, One side head ache, Piles, Ringworm tinea, Hemiplegia, Hepatitis B (two types of plants), and rest Diabetes, Scorpion bite, Hepatitis C, Hepatitis A Calculi, Psoriasis, and Centipede bite single plant are used to cure the diseases (Fig 5). The frequent use of multiple plant remedies among the traditional healers could be attributed to the belief of synergic reactions where one plant could have a potentiating effect than other. It is believed that multiple prescriptions contain a range of pharmacologically active compounds and poly-herbal treatment has more healing power than single medicinal plant treatment, since each medicinal plant used in the mixture is a remedy 21 .

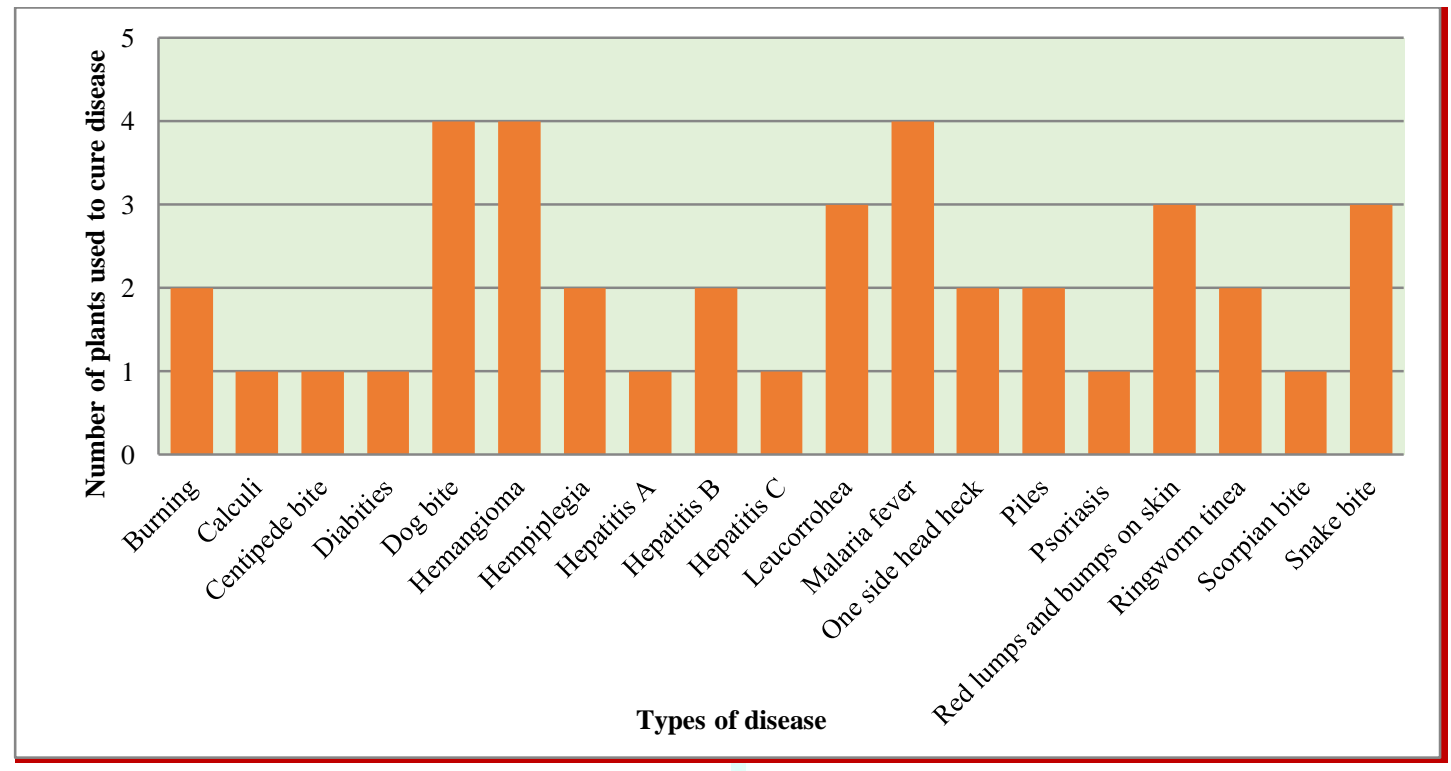

Figure 5: Number of plants used to cure various Diseases

Herbal formulations were administrated either internally or applied externally depending on the type of ailment. Most remedies were administrated orally (63\%) for relieving diseases and disorders like Snake bite, Malaria fever, Diabetes, Scorpion bite, Hepatitis C, Leucorrhoea, Hepatitis A, Piles, Hemiplegia, Calculi, Hepatitis B, Psoriasis and Centipede bite, followed by Topical administration (32\%) for Burning, Red lumps and bumps on skin, Haemangioma, Dog bite and Ringworm tinea, and nasal administration (5\%) for one side headache (Fig 6). Majority of the herbal remedies were prepared in the form of Decoction and paste both each with $30 \%$, followed by tonic $(20 \%)$, chewing and syrup both each with $10 \%$ (Fig 7). The mode of administration of the herbal formulations in Berbere district of Oromia region, Ethiopia is mainly oral 22. In case of skin diseases and wounds, healers applied herbal medicine topically. The administration of herbal remedies orally or externally depended on the disease and drug formulation.

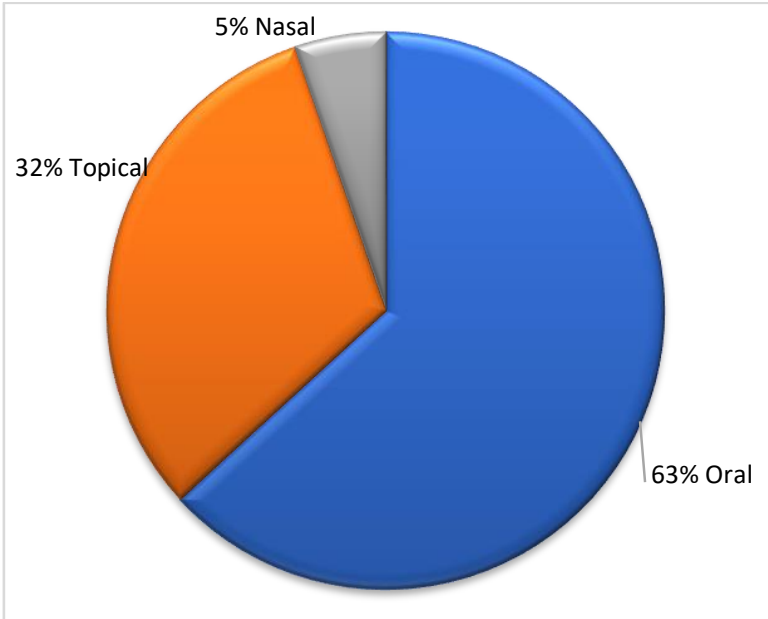

Figure 6: Routes of administration

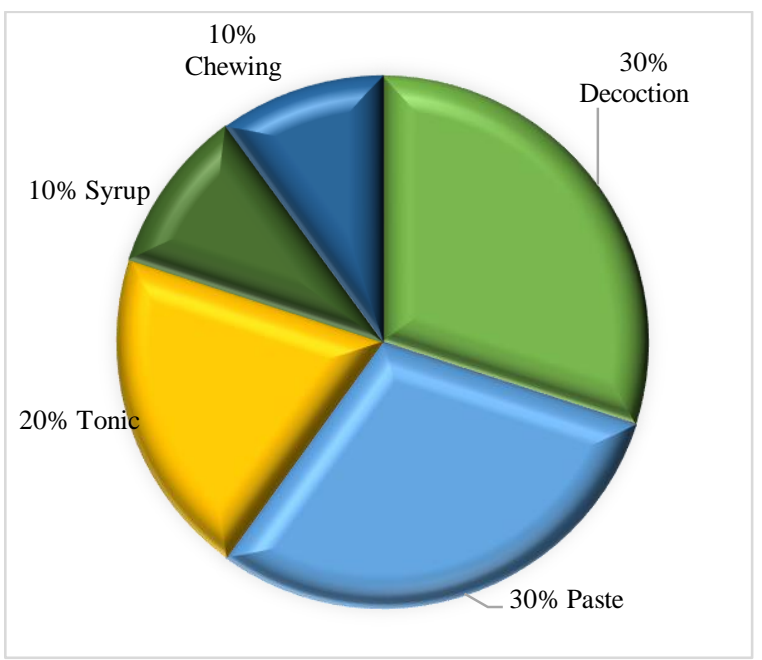

Figure 7: Modes of preparation used by traditional healers 


\section{Nagalakshmi et al}

The traditional healers usually collect the plants in the field, dry and crush them, before storing the plant material in bottles. This is often done to prevent patients from recognizing the plants being used for their treatment, which may sometimes be a seemingly ordinary plant growing in their gardens or across the street or in the field or majority in the field. Some healers prefer stringing plant material in powdered form in bottles to reduce the number of field collection trips they may otherwise be obligated to undertake or to stroke up inventory for times when some plants may be seasonably unavailable, so as to be able to offer treatments throughout the year.

High ICF values are obtained when only one or a few plant species are reported to be used by a high proportion of
Journal of Drug Delivery \& Therapeutics. 2020; 10(1):39-47

informants to treat a particular ailment where as low ICF values indicate that informants disagree over which plant to use. The high ICF value of 1 in the following ailment categories; Burning, one side head heck, Dog bite, Ringworm tinea. The low $F_{\text {ic }}$ values of 0.66 in the following ailment categories; Malaria fever and Hemangioma. The $F_{\text {ic }}$ value of zero (0) in the following ailment categories; Snake bite, Diabities, Scorpian bite, Leucorrohea, Hepatities A, Piles, Hemiplegia, Calculi, Hepatitis B, Soriasis, Centipede bite (Table 3). However, the average ICF value for all disease categories was 0.56 which is considerably high as compared to similar studies conducted from other countries 23 .

Table 3: Informant Consensus agreement about use of medicinal plants for ailment categories

\begin{tabular}{|l|l|l|l|l|}
\hline Sl. No. & Ailment & $\mathbf{N}_{\mathbf{u r}}$ & $\mathbf{N}_{\mathbf{t}}$ & $\mathbf{I C F}$ \\
\hline 1 & Burning & 2 & 1 & 1 \\
\hline 2 & Calculi & 1 & 1 & 0 \\
\hline 3 & Centipede bite & 1 & 1 & 0 \\
\hline 4 & Diabetes & 1 & 1 & 0 \\
\hline 5 & Dog bite & 4 & 1 & 1 \\
\hline 6 & Hemangioma & 4 & 2 & 0.66 \\
\hline 7 & Hemiplegia & 2 & 2 & 0 \\
\hline 8 & Hepatitis A & 1 & 1 & 0 \\
\hline 9 & Hepatitis B & 2 & 2 & 0 \\
\hline 10 & Hepatitis C & 1 & 1 & 0 \\
\hline 11 & Leucorrhoea & 3 & 3 & 0 \\
\hline 12 & Malaria fever & 4 & 2 & 0.66 \\
\hline 13 & One side head heck & 2 & 1 & 1 \\
\hline 14 & Piles & 2 & 2 & 0 \\
\hline 15 & Psoriasis & 1 & 1 & 0 \\
\hline 16 & Red lumps and bumps on skin & 3 & 3 & 0 \\
\hline 17 & Ringworm tinea & 2 & 1 & 1 \\
\hline 18 & Scorpion bite & 1 & 1 & 0 \\
\hline 19 & Snake bite & 3 & 3 & 0 \\
\hline
\end{tabular}

\section{CONCLUSION}

This study shows a wide diversity of plant species used as remedies for several ailments. Such plants are very useful especially to people who cannot afford modern medicinal care and in cases where access to modern health facilities is not easy. Knowledge and use of herbal medicine for treatment of various ailments among the local people is still part of their life and culture and preservation of the integrity of the folk knowledge of herbal medicine. The documented plants have potential of being used in pharmaceutical drug development.

\section{ACKNOWLEDGEMENT}

Authors are thankful to the Management and Principal of JSS College of Arts, Commerce and Science, Mysore, India for providing necessary laboratory facilities to carry out the experimental work.

\section{REFERENCES}

1. Geerisha J \& Raju N. Ethnobotanical study of medicinal plants in BR hills region of Western Ghats, Karnataka, Asian journal of plant science and research, 2013; 3(5): 36-40.
2. Mahwasane ST, Middleton L \& Boaduo N. An ethnobotanical survey of indigenous knowledge on medicinal plants used by the traditional healers of the Lawamondo area, Limpop province, South Africa. South African journal of Botany, 2013; 88: 69-75.

3. Ganapathy S, Ramaiah M, Sarala S \& Babu M. Ethnobotanical survey of three Indian medicinal plant. International journal of research, 2013; 4(3): 14.

4. Cheikhyoussef A, Shapi M, Matengu K \& Ashekele HM. Ethnobotanical study of indigenous knowledge on medicinal plant use by traditional healers in Oshikoto region, Nambia. Journal of ethnobiology and ethnomedicine, 2011; 7(10): 1-11.

5. Benarba B. Medicinal plants used by traditional healers from south-west Algeria. Journal of Intercultural ethnopharmacology, 2016; 5(4): 320-330.

6. Cron GV. Medicinal plants used by traditional healers from South Africa, South African journal of Botany, 2013; 88: 10-16.

7. Khan I, Abdelasalam NM, Fouad H, Tariq UR \& Adnan M. Application of ethnomedicinal indices on the use of traditional medicines against common diseases. Hindawi research article, 2014; 6(1): 1-21.

8. Abbouyi PAE, Ansari NF, Khyari PSE \& Loukilli H. Inventory of medicinal plants prescribed by traditional healers in EI Jadida city and suburbs. International journal of Green Pharmacy, 2014; 4(4): 242-251. 


\section{Nagalakshmi et al}

9. Nandini N \& Siddamallayya N. Diversity of medicinal plants flora of old Mysore District, Karnataka, India. Indo American journal of pharmaceutical Research, 2013; 3(8): 6248-6258.

10. Tugume P, Kakudidi EK, Buyinza M, Namaalwa J \& Kamatenesis M. Ethnobotanical survey of medicinal plants species used by communities around Mabira central forest Reserve, Uganda Journal of ethnobiology and ethnomedicine, 2016; 12(5): 1-28.

11. Sharanappa R \& Vidyasagar GM. Documentation of traditional knowledge on medicinal plants used in treating candidiasis in Hyderabad Karnataka region, India. World journal of pharmacy and pharmaceutical sciences, 2014; 3(7): 739-751.

12. Guruprasad SL, Ningaiah MR \& Gangadhar. Indigenous knowledge on medicinal plants among the Iruliga tribal population of Western Ghats areas, Karnataka, India. Physical Anthropology, 2013; 9(1): 195-203.

13. Ngarivhume T, Klooster VC, Jong JT \& Van der Westhuizen JH Medicinal plants used by traditional healers for the treatment of malaria in the Chipinge district in Zimbabwe. Journal of Ethnopharmacology, 2015; 159:224-37.

14. Fiscal RR. Ethnomedicinal plants used by traditional healers in Laguna, Philippines. Asia Pacific journal of multidisciplinary research, 2017; 5(4): 132-137.

15. Pandey AK \& Tripathi YC. Ethnobotany and its relevance in contemporary research. Journal of medicinal plants studies, 2017; 5(3): 123-129.

16. Uniyal SK, Singh KN, Jamwal P \& Lal B. Traditional use of medicinal plants among the tribal communities chhota bhangal, Western Himalaya. Journal of ethnobiology and ethnomedicine, 2006; 2(4): 1-8.
Journal of Drug Delivery \& Therapeutics. 2020; 10(1):39-47

17. Bekalo TH, Woodmatas SD \& Woldemariam ZA. An ethnobotanical study of medicinal plants used by local people in the lowlands of Konta special woreda, Southern nations, nationalities and peoples regional state, Ethiopia. Journal of Ethnobiology and Ethnomedicine, 2009; 5(6): 1-15.

18. Manjula S \& Mamidala E. An ethnobotanical survey of medicinal plants used by traditional healers of Thadvai, Warangal district, Andhra Pradesh, India. International journal of medical research health sciences, 2012; 2(1): 40-46.

19. Raj AJ, Biswakarma S, Pala NA, Shukla G, Vineeta, Kumar M, Chakravarty S \& Bussmann RW. Indigenous uses of ethnomedicinal plants among forest-dependent communities of Northern Bengal, India. Journal of Ethnobiology and Ethnomedicine, 2018, 14(8): 1-28.

20. Rai R. Promising medicinal plants their parts and formulations prevalent in folk medicines among ethnic communities in Madhya Pradesh, India. Pharmacy \& Pharmacology International Journal, 2017, 5(3): 99-106.

21. Ayyanar M \& Ignacimuthu S. Ethnobotanical survey of medicinal plants commonly used by Kani tribals in Tirunelveli hills of Western Ghats, India. Journal of Ethnopharmacology, 2011, 134: 851-864.

22. Jima TT \& Megersa M. Ethnobotanical Study of Medicinal Plants Used to Treat Human Diseases in Berbere District, Bale Zone of Oromia Regional State, South East Ethiopia. Evidence-Based Complementary and Alternative Medicine, 2018, 1-16.

23. Kigen G, Kumuren Z, Njiru E, Wanjohi B \& Kilpkore W. Ethnomedicinal survey of the plants used by traditional healers in Narok country, Kenya. Evidence-Based Complementary and Alternative Medicine, 2019; 10(11): 1-8. 